\author{
Y.B. Raiymbekov, U. Besterekov, P.A. Abdurazova \\ M. Auezov South Kazakhstan State University, Shymkent, Kazakhstan \\ (E-mail: eplusr@bk.ru)
}

\title{
Review of methods for enrichment of phosphate raw materials in the world
}

\begin{abstract}
With the development of the global economy, the consumer market for phosphorus-containing products is growing. All existing deposits of rich phosphorites are being depleted. In this regard, there is a need to involve in the production of low-grade phosphorites and substandard phosphate raw materials, which are currently little studied and are not used. For the processing of substandard phosphorites, there is a need for new methods for improving and enriching low-grade ores and removing impurities as much as possible in order to increase the content of the target components and improve the suitability for processing. The article provides modern information about the processes of enrichment of phosphorites in different countries. This information is fundamental for further research on the enrichment of Karatau phosphorites. The review is made mainly of two methodsflotation (applicable for silicate phosphates) and the use of organic acids (for carbonate substances). The mechanisms of separation of substances during flotation enrichment and decomposition of carbonate minerals using of organic acids are described. The advantages and disadvantages of each method are considered. It is established that the choice of a certain method is determined by the mineralogical structure and chemical composition of phosphorites.
\end{abstract}

Keywords: phosphorite, deposit, chemical industry, production, enrichment, flotation, substandard raw materials, low-grade ores.

\section{Introduction}

Phosphorites are sedimentary rocks with a content of $\mathrm{P}_{2} \mathrm{O}_{5}-$ from $5 \%$ to $30 \%$, a significant part of which consists of phosphates close in composition to the Apatite group and are represented by hidden or microcrystalline formations. Natural phosphates serve as raw materials for obtaining elemental phosphorus and its various compounds. More than $90 \%$ of all extracted phosphorus is used for the production of mineral fertilizers.

The world raw material potential of natural phosphates-apatites and phosphorites is estimated at about 30 billion $\mathrm{t}_{2} \mathrm{O}_{5}$. Structurally, it is almost $95 \%$ represented by phosphorites and only $5 \%$ is accounted for by apatites, and in Russia apatites are sharply predominant (80\%). Africa (Morocco, Tunisia, Western Sahara, South Africa) holds the leading position in terms of reserves of phosphate ores, and America (USA, Peru, Mexico, Brazil) is in second place. The Asian continent is characterized by the largest reserves of phosphorites in China, Jordan, Mongolia, and Saudi Arabia. Australia has significant reserves of phosphorites. About $80 \%$ of the total world production (130 million tons of commodity ore) is accounted for by the United States, Morocco, Russia, Kazakhstan, and China. The leading producers of phosphorus concentrate are the United States (36 million tons) and Morocco (20 million tons). The leading positions in the production of apatite concentrate are occupied by Russia ( 4.5 million tons), Brazil (3 million tons), and South Africa (2.5 million tons) [1].

The Republic of Kazakhstan occupies the fourth place in the world in terms of reserves of phosphate raw materials and is the largest phosphate raw material base in Eurasia. Today, about 45 deposits of phosphorites have been explored. Among them, the resources of Karatau phosphorite ores are more than 15 billion tons of $\mathrm{P}_{2} \mathrm{O}_{5}$, where the largest deposits are Zhanatas, Kokzhon, Koksu, Aksai and Akzhar. However, all the abovementioned countries of the world, including Kazakhstan, have depleted the resources of the rich in $\mathrm{P}_{2} \mathrm{O}_{5}$ content. In this regard, the use of low-grade phosphorites is required, but their processing requires an enrichment process [2].

\section{Discussion}

Usually, flotation, thermal (calcination) and mechanical methods are used for ore phosphorite enrichment in practice. Flotation is of great importance as a secondary method of enrichment, and is used in the enrichment of phosphorites. The method is based on the different ability of minerals to wetting with water. Through an aqueous suspension of crushed solid ore, air is blown from below with small bubbles. Hydrophobic particles of raw materials (apatite) adhere to air bubbles and are carried out with their help to the surface. The formed 
foam is collected in special receivers. The flotation concentrate is obtained after the destruction of the foam solid residue. There are difficulties in the enrichment of sedimentary rocks (phosphorites) with carbonate impurities, since they are resistant to flotation.

For example, the enrichment of Karatau phosphorites occurs at the processing plants in Zhanatas and Karatau city in the Zhambyl region. In many cases, these processing plants are enriched with phosphorites of siliceous-carbonate composition and use a combined method-chemical-flotation and suspension-flotation. The essence of the combined method is that at the first stage, after crushing the ore and screening the fraction, suspension enrichment is carried out. In this case, a mixture of acidic sodium salts of aliphatic polyphosphoric acids with the name «Flotol-7.9» is used as a flotation reagent. At the second stage, carbonate flotation of the heavy fraction is carried out. Increasing the content of $\mathrm{P}_{2} \mathrm{O}_{5}$ is achieved by the fact that the enrichment is partially removed siliceous rock (with a light fraction and slime) and reduces the volume of slime, clay particles. This method was used for the phosphorites of the Aksai deposit, where the initial ore contained $\mathrm{P}_{2} \mathrm{O}_{5} 21.6 \%, \mathrm{MgO} 3.48 \%$, and an insoluble residue $21.9 \%$. The overall results of the combined scheme were: $\mathrm{P}_{2} \mathrm{O}_{5} 30.2 \%, \mathrm{MgO} 1.75 \%$, insoluble residue $13.46 \%$. The obtained indicators of the content of basic substances indicate the suitability of the enriched product for further processing [2].

It is known that various collectors and depressants are used for flotation. Fatty acids [3], amphoteric derivatives of amines [4] and others are considered as collectors and depressants. In Brazil, natural flotation reagents such as coconut oil and starch were used to enrich low-grade phosphorites in the Itataya field, Ceara state with a content of $17.34 \% \mathrm{P}_{2} \mathrm{O}_{5}, 20.78 \% \mathrm{CaCO}_{3}$ and $24.14 \% \mathrm{SiO}_{2}$ for flotation [5]. As a result, the content of $\mathrm{P}_{2} \mathrm{O}_{5}$ in the concentrate at $80.8 \%$ extraction reached $30.5 \%$.

In the same country, scientists [6] conducted a laboratory study using a collector in the form of soy bran oil, Flotanol D25 (polyalkylene glycol ether foamer), sodium hydroxide, phosphoric acid, citric acid and carbon dioxide. The initial composition of phosphorites: $17.73 \% \mathrm{P}_{2} \mathrm{O}_{5}, 34.00 \% \mathrm{CaCO}_{3}$ and $24.14 \% \mathrm{SiO}_{2}$. In the first stage, soy bran oil and Flotanol D25 were used to separate the insoluble residue. In the second stage, the effectiveness of phosphoric and citric acid for the extraction of carbonates was investigated. When using citric acid, the $\mathrm{P}_{2} \mathrm{O}_{5}$ content reached $32.46 \%$ (product yield $87.3 \%$ ), and when using phosphoric acid $\mathrm{P}_{2} \mathrm{O}_{5} 27.86 \%$ (product yield $87.6 \%$ ).

A study of two-stage calcite flotation followed by phosphorite flotation was also conducted. For flotation of calcite are used the same collectors - soybean bran oil, Flotanol D25 and carbon dioxide. The addition of carbon dioxide is explained by the fact that it reduces the strength of hydrogen bonds and facilitates the adsorption of the reservoir. For flotation of phosphorite used sodium hydroxide and soybean bran oil. As a result, the flotation concentrate had $32.48 \%$ of $\mathrm{P}_{2} \mathrm{O}_{5}$. The presence of carbon dioxide increased the selectivity of calcite flotation in relation to phosphorite even when using a low collector dosage by suppressing the electrostatic barrier for adsorption of the anion collector [6].

The phosphorites of the Guizhou deposit (China) are classified by scientists as low-grade phosphorites according to the content of $\mathrm{P}_{2} \mathrm{O}_{5} 23.56 \%$, while this content belongs to ordinary ones. But nevertheless, regarding the phosphorites of this Deposit, research was undertaken on enrichment by the method of reverse flotation, where rapeseed oil was used as flotation reagents in combination with the de-magnesium collector EM-LS-01. By studying the flotation characteristics of various fatty acids, scientists obtained the flotation agent EM-LS-01 by saponification, amidation and addition of surfactants. The effectiveness of the flotation agent was proved on Guizhou phosphorites, where the results obtained flotation concentrate with $\mathrm{P}_{2} \mathrm{O}_{5} 30.25 \%$ with a product yield of $90.63 \%$. The authors argue that it is necessary to study the composition and nature of fatty acids, and deduce the hypothesis that the higher the content of linoleic acid in vegetable oils, the better the performance of flotation [7].

The economic component of the flotation process is touched in the investigations of Chinese scientists. They conducted research to reduce the dosage of flotation reagents using the gravity-flotation method for the phosphorites of the Yichang deposit in Hubei province. In the first stage, using gravitational separation, it was possible to obtain a gravitational concentrate with $\mathrm{P}_{2} \mathrm{O}_{5}$ of $28.95 \%$. In the future, flotation was performed with the resulting concentrate, where liquid glass, sodium oleate and sodium dodecyl sulfate were used as flotation reagents for comparison. Because of its mineralogical structure, the main mineral in these phosphorites is dolomite. In this regard, sodium dodecyl sulfate is a collector of dolomite. The study resulted in a flotation concentrate with $\mathrm{P}_{2} \mathrm{O}_{5}$ of $30.36 \%$ with a product yield of $75.36 \%$. The improved gravity-flotation combined process has proven to be effective in reducing the flow rate of flotation reagents from $6.1 \mathrm{~kg} / \mathrm{t}$ to $3.9 \mathrm{~kg} / \mathrm{t}$ with similar separation results [8]. 
Promising research on phosphorite enrichment is also being conducted in Africa. For example, in Zimbabwe, The Mumbwa phosphorite deposit is $22.7 \%$ in terms of the main component $\mathrm{P}_{2} \mathrm{O}_{5}$. In laboratory conditions, flotation was performed using petroleum sulfonate as a collector. The results of the study allowed to obtain a flotation concentrate with $\mathrm{P}_{2} \mathrm{O}_{5}$ content of about $37 \%$ at the optimal dosage of the flotation agent $1100 \mathrm{~g} / \mathrm{t}[9]$.

Of the African countries in terms of phosphorite reserves, Tunisia stands out, where deposits of phosphorites are located in the Gafsa-Metlaoui basin in the South of the country. The Tozeur-Nefta field is a very important resource for the economy of this country, where according to data there are 410 million tons of phosphates. But it was not previously used in industrial scale because of the low content of $\mathrm{P}_{2} \mathrm{O}_{5}$ (about $12-$ $16 \%$ ). Before flotation, the raw material underwent mechanical treatment, which resulted in raw materials with $\mathrm{P}_{2} \mathrm{O}_{5} 15.5 \%$. Phosphoric acid was used as an anion collector to remove carbonate impurities. According to the results of the study, the $\mathrm{P}_{2} \mathrm{O}_{5}$ of the flotation concentrate was $27.1 \%$, but the $\mathrm{CaO} / \mathrm{P}_{2} \mathrm{O}_{5}$ ratio of 1.71 is high and makes the product unsuitable for industrial use [10]. In addition, use as a flotation agent is economically unprofitable due to the high cost.

In this regard, the following work is a study of the enrichment of phosphorites in Egypt, where phosphoric acid was completely replaced by oleic acid mixed with kerosene (in a ratio of 1:1) as a collector. High-grade sodium carbonate, hydrochloric acid, and bromoform were used as $\mathrm{pH}$ regulators for comparison. For laboratory research, crushed ore was used $0.25 \mathrm{~mm} \pm 0.074 \mathrm{~mm}$. The $\mathrm{P}_{2} \mathrm{O}_{5}$ content was $19.59 \%$. When using bromoform, the $\mathrm{P}_{2} \mathrm{O}_{5}$ content increased to $33.43 \%$. But due to its toxicity, it is forbidden to use bromoform in industry. Studies with a mixture of oleic acid with kerosene allowed increasing $\mathrm{P}_{2} \mathrm{O}_{5}$ up to $30 \%$. The mechanism of interaction of this mixture with phosphorite is explained by the fact that at low $\mathrm{pH}$ oleic acid is essentially present in the form of neutral molecules. Consequently, these neutral molecules physically bind to the calcite surface, which is slightly positively charged, by hydrogen bonding with $\mathrm{H}_{2} \mathrm{CO}_{3}$, improving the selective flotation of calcite [11].

Also in Egypt the method of enrichment of phosphorites by acid leaching with the use of inorganic and organic acids has been studied. Inorganic acids are strong in comparison with organic ones, and in the leaching process carry away a part of the phosphorites, which are subjected to the action of a strong acid. For example, the phosphorites of the Abu Tartour deposit (Egypt) have a $\mathrm{P}_{2} \mathrm{O}_{5}$ of $21.8 \% .4$ organic acids were selected for leaching, namely acetic acid, tartaric acid, citric acid and oxalic acid. The authors note the cost-effectiveness of using organic acids to remove carbonate impurities and the solubility/digestibility of phosphates in the final product. The process of leaching with organic acids is carried out at relatively low temperatures and concentrations, since with an increase in the temperature of the process and the concentration of the acid, the transition of phosphates to the solution is possible. The studies were conducted in laboratory conditions at room temperature and reaction time equal to $30 \mathrm{~min}$. The ratio of $\mathrm{S}: \mathrm{L}$, is respectively, 1:2. The concentration of the acid is $0.2,0.8$ and $1.4 \mathrm{M}$ in terms of leaching efficiency, tartaric acid was the weakest, followed by citric and acetic acid. The use of oxalic acid increased the $\mathrm{P}_{2} \mathrm{O}_{5}$ content to $28 \%$ [12].

Similar studies on the use of organic acids have been conducted in China. Phosphorites from the Xinhua deposit with a $\mathrm{P}_{2} \mathrm{O}_{5}$ content of $17.45 \%$ were selected for study. The organic acids selected for leaching were diluted, thereby reducing the concentration. This is due to the fact when water is diluted with organic acid, the contact surface between the dolomite and the acid increases. Meanwhile, acids with high concentrations do not react with calcium and magnesium carbonate due to the high polarity of the $\mathrm{O}-\mathrm{H}$-bond of the acid molecules. In comparison with the previous work, the reaction time was increased to 40-60 minutes and the temperature to $40{ }^{\circ} \mathrm{C}$. At 30 minutes of reaction and at $40{ }^{\circ} \mathrm{C}, \mathrm{P}_{2} \mathrm{O}_{5}$ is reached $33.78 \%$. When increasing the time already at 40 minutes revealed a slight entrainment of phosphates in the solution, but the removal of the carbonate component improved. The results of the study are confirmed by thermodynamic methods of analysis, the data of which indicate the primary leaching of carbonates than phosphates [13].

Leaching with organic acids was also studied in Uzbekistan of Kyzylkum phosphorites of the ZheroySardar deposit with a $\mathrm{P}_{2} \mathrm{O}_{5}$ content of $16.2 \%$. Acetic and formic acids were used as leachable reagents. As a result of the conducted laboratory research, the optimal stoichiometric norm of acetic and formic acids was established in the limit of $110 \%$, the time of $240 \mathrm{~min}$ and the temperature of $25^{\circ} \mathrm{C}$. The content of $\mathrm{P}_{2} \mathrm{O}_{5}$ in the final enriched product was $23.27 \%$, which is suitable for obtaining phosphorus and phosphoric acid. In this case, the regeneration of waste acid, as stated here and in previous works is carried out with sulfuric acid [14]. The process of regeneration has not studied yet been fully, since the process of leaching with organic acids has not introduced yet been into production anywhere in the world. 


\title{
Conclusions
}

The use of organic acids is characterized by high efficiency, low cost, simple operating conditions (room temperature and atmospheric pressure), the possibility of organic acid regeneration, preservation of the surface properties of the resulting phosphate. In addition, it does not cause any special environmental hazards due to the produced by-product in the form of pure calcium sulfate (gypsum) in comparison with phosphogypsum obtained by sulfuric acid decomposition. In industrial applications, organic acids have a weakly pronounced corrosive effect.

In conclusion, the identification of new, technologically optimal, cost-effective, environmentally safe opportunities for enrichment of substandard phosphorous raw materials and the implementation of the results in production is an urgent task for researchers.

\section{References}

1 Besterekov U. Chemistry and Technology of Inorganic Substances: tutorial / U. Besterekov, M. Yeskendirova, G. Seitmagzimova. - Shymkent: M. Auezov South Kazakhstan State University, 2017. — 377 p.

2 Kiperman Yu.A. Phosphates for the XXI century: monograph / Yu.A. Kiperman. - Almaty-Taraz-Zhanatas: Kazphosphate LLP, 2006. - 208 p.

3 Al-Fariss T.F. Flotation of a carbonate rich sedimentary phosphate rock / T.F. Al-Fariss, H.O. Ozbelge, A.M. Abdulrazik // Fertilizer Research. — 1991. — Vol. 29. - P. 203-208.

4 Houot R. Selective flotation of phosphatic ores having a siliceous and/or a carbonated gangue / R. Houot, R. Joussemet, J. Tracez, R. Brouard // International Journal of Mineral Processing. — 1985. — Vol. 14. — P. 245-264.

5 Albuquerque R.O. Pilot Scale Direct Flotation of a Phosphate Ore with Silicate-Carbonate Gangue / R.O. Albuquerque, A.E.S. Peres, J.A. Aquino, P.E. Praes, C.A. Pereira // Procedia Engineering. — 2012. — Vol. 46. — P. 105-110.

6 Albuquerque R.O. Flotation Routes for a Phosphate Ore Bearing Silicate-Carbonate Gangue / R.O. Albuquerque, A.E.S. Peres, J.A. Aquino, C.A. Pereira // Revista De La Facultad De Ingenieria. — 2012. — Vol. 27. — P. 26-32.

7 Cheng X. Study on Collector for Reverse Flotation of Certain Phosphorite in Guizhou / X. Cheng, R. Li, Ch. Ju, H. L. Hui // Advanced Materials Research. — 2013. - Vol. 734-737. — P. 1086-1092.

8 Kun S. Application and Mechanism of Anionic Collector Sodium Dodecyl Sulfate (SDS) in Phosphate Beneficiation / S. Kun, L. Tao, Zh. Yimin, L. Xin, W. Bo, X. Chengbao // Minerals. — 2017. - Vol. 7, Iss. 2. — P. 29.

9 Lukomona C. The beneficiation of Mumbwa phosphate deposit by various techniques / C. Lukomona, J.B. Mwalula, L.K. Witika // African Journal of Science and Technology. — 2005. — Vol. 6, Iss. 2. — P. 113-119.

10 Haifa B. The Beneficiation Process of Low-Grade Sedimentary Phosphates of Tozeur-Nefta Deposit (Gafsa-Metlaoui Basin: South of Tunisia) / B. Haifa, D. Ghassen, T. Haifa, S. Radhia, C. Noureddine, F. Nabil, S. Fouad // Minerals. - 2019. — Vol. 9, Iss. 1.

11 Tawfik R.B. A modification in the flotation process of a calcareous-siliceous phosphorite that might improve the process economics / R.B. Tawfik, Y. Ahmed, S.I. Suzan, Y.E. Khaled // Minerals Engineering. — 2014. — Vol. 69. — P. 97-101.

12 Bakry A.R. Upgrading of Abu-Tartur calcareous phosphate via selective leaching by organic acids / A.R. Bakry, N.A. Abdelfattah, A.B. Farag, A.M. Elwy// International Journal of Scientific \& Engineering Research. — 2015. — Vol. 6, Iss. 10. — P. 5764.

13 Fei X. Research on Enrichment of $\mathrm{P}_{2} \mathrm{O}_{5}$ from Low-Grade Carbonaceous Phosphate Ore via Organic Acid Solution / X. Fei, Zh. Jie, Ch. Jiyan, W. Jianrui, W. Lin // Journal of Analytical Methods in Chemistry. — 2019. — Vol. 2019. — P. 7.

14 Seitnazarov A. Beneficiation of High-Calcareous Phosphorites of Central Kyzylkum with Organic Acid Solutions / A. Seitnazarov, S. Namazov, B. Beglov // Journal of Chemical Technology and Metallurgy. — 2014. — Vol. 49, Iss. 4. — P. 383-390.

\section{Е.Б. Райымбеков, У. Бестереков, П.А. Абдуразова}

\section{Әлемдегі фосфат шикізатын байыту әдістеріне шолу}

\begin{abstract}
Жаһандық экономиканың дамуымен фосфорлы өнімдерді тұтыну нарығы өсуде. Қазіргі кездегі бай фосфориттердің кен орындары сарқылуда. Осыған байланысты кедей фосфориттер мен кондициялық емес фосфат шикізатын өндіріске тарту қажеттілігі туындайды, олар қазіргі уақытта аз зерттелген және қолданусыз жатыр. Жарамдылығы төмен фосфориттерді қайта өңдеу үшін төмен сұрыпты кендерді байытудың және мақсатты компоненттердің құрамын ұлғайту мен қайта өңдеуге жарамдылығын жақсарту мақсатында қоспаларды барынша жоюдың жаңа әдістеріне қажеттілігі туындайды. Мақалада түрлі елдердің фосфорит байыту процестері туралы заманауи мәліметтер берілген. Бұл мәліметтер Қаратау фосфориттерін одан әрі байытуды зерттеу үшін негізге алынатын ақпарат болып табылады. Негізінен екі әдіс — флотация (силикатты фосфаттар үшін қолданылады) және органикалық қышқылдарды пайдалану (карбонатты заттар үшін). Флотациялық байыту және органикалық қышқылдарды қолданудағы карбонатты минералдардың ыдырауы кезінде заттардың бөліну механизмдері сипатталған. Әр
\end{abstract}


тәсілдің артықшылықтары мен кемшіліктері қарастырылған. Белгілі бір әдісті таңдау фосфориттердің минералогиялық құрылымымен және химиялық құрамымен байланысты екені анықталған.

Кілт сөздер: фосфорит, кен орны, химия өнеркәсібі, өндіріс, байыту, флотация, жарамдылығы төмен шикізат, төмен сұрыпты кендер.

\author{
Е.Б. Райымбеков, У. Бестереков, П.А. Абдуразова
}

\title{
Обзор методов обогащения фосфатного сырья в мире
}

\begin{abstract}
С развитием глобальной экономики возрастает потребительский рынок в фосфорсодержащих продуктах. Все ныне существующие месторождения богатых фосфоритов истощаются. В связи с этим возникает необходимость вовлечь в производство бедные фосфориты и некондиционное фосфатное сырье, которые в данное время мало изучены и не используются. Для переработки некондиционных фосфоритов возникает необходимость в новых методах улучшения и обогащения низкосортных руд и максимально возможного удаления примесей в целях увеличения содержания целевых компонентов и улучшения пригодности к переработке. В статье приведены современные сведения о процессах обогащения фосфоритов разных стран. Эти сведения являются основополагающими для дальнейших исследований обогащения фосфоритов Каратау. Сделан обзор преимущественно двух методов - флотации (применимо для силикатных фосфатов) и использование органических кислот (для карбонатных веществ). Описаны механизмы разделения веществ при флотационном обогащении и разложении карбонатных минералов при применении органических кислот. Рассмотрены преимущества и недостатки каждого способа. Установлено, что выбор определенного метода обусловливается минералогическим строением и химическим составом фосфоритов.
\end{abstract}

Ключевые слова: фосфорит, месторождение, химическая промышленность, производство, обогащение, флотация, некондиционное сырье, низкосортные руды.

\section{References}

1 Besterekov, U., Yeskendirova, M., \& Seitmagzimova, G. (2017). Chemistry and Technology of Inorganic Substances. Shymkent, Kazakshtan: M. Auezov South Kazakhstan State University.

2 Kiperman, Yu.A. (2006). Phosphates for the XXI century. Almaty-Taraz-Zhanatas: Kazphosphate LLP.

3 Al-Fariss, T.F., Ozbelge, H.O., \& Abdulrazik, A.M. (1991). Flotation of a carbonate rich sedimentary phosphate rock. Fertilizer Research, 29, 203-208.

4 Houot, R., Joussemet, R., Tracez, J., \& Brouard, R. (1985). Selective flotation of phosphatic ores having a siliceous and/or a carbonated gangue. International Journal of Mineral Processing, 14, 245-264.

5 Albuquerque, R.O., Peres, A.E.S., Aquino, J.A., Praes, P.E., \& Pereira, C.A. (2012). Pilot Scale Direct Flotation of a Phosphate Ore with Silicate-Carbonate Gangue. Procedia Engineering, 46, 105-110. DOI: 10.1016/j.proeng.2012.09.452

6 Albuquerque, R.O., Peres, A.E.S., Aquino, J.A., \& Pereira, C.A. (2012). Flotation Routes for a Phosphate Ore Bearing SilicateCarbonate Gangue. Revista De La Facultad De Ingenieria, 27, 26-32.

7 Cheng, X., Li, R., Ju, Ch., \& Hui, H.L. (2013). Study on Collector for Reverse Flotation of Certain Phosphorite in Guizhou. Advanced Materials Research, 734-737, 1086-1092. DOI: 10.4028/www.scientific.net/AMR.734-737.1086

8 Kun, S., Tao, L., Yimin, Zh., Xin, L., Bo, W., \& Chengbao, X. (2017). Application and Mechanism of Anionic Collector Sodium Dodecyl Sulfate (SDS) in Phosphate Beneficiation. Minerals, 7, 2, 29. DOI: 10.3390/min7020029

9 Lukomona, C., Mwalula, J.B., \& Witika, L.K. (2005). The beneficiation of Mumbwa phosphate deposit by various techniques. African Journal of Science and Technology, 6, 2, 113-119. DOI: 10.4314/ajst.v6i2.55182

10 Haifa, B., Ghassen, D., Haifa, T., Radhia, S., Noureddine, C., Nabil, F., \& Fouad, S. (2019). The Beneficiation Process of LowGrade Sedimentary Phosphates of Tozeur-Nefta Deposit (Gafsa-Metlaoui Basin: South of Tunisia). Minerals, 9, 1. DOI: $10.3390 / \min 9010002$

11 Tawfik, R.B., Ahmed, Y., Suzan, S.I., \& Khaled, Y.E. (2014). A modification in the flotation process of a calcareous-siliceous phosphorite that might improve the process economics. Minerals Engineering, 69, 97-101. DOI: 10.1016/j.mineng.2014.07.017

12 Bakry, A.R., Abdelfattah, N.A., Farag, A.B., \& Elwy, A.M. (2015). Upgrading of Abu-Tartur calcareous phosphate via selective leaching by organic acids. International Journal of Scientific \& Engineering Research, 6, 10, 57-64.

13 Fei, X., Jie, Zh., Jiyan, Ch., Jianrui, W., \& Lin, W. (2019). Research on Enrichment of $\mathrm{P}_{2} \mathrm{O}_{5}$ from Low-Grade Carbonaceous Phosphate Ore via Organic Acid Solution. Journal of Analytical Methods in Chemistry, 2019, 7. DOI: 10.1155/2019/9859580

14 Seitnazarov, A., Namazov, S., \& Beglov, B. (2014). Beneficiation of High-Calcareous Phosphorites of Central Kyzylkum with Organic Acid Solutions. Journal of Chemical Technology and Metallurgy, 49, 4, 383-390. 